Yıl: 23 Cilt: 23 Sayı: 2 Aralık 2021 s.158-177 Makale Türü: Araştırma

Makalenin Geliş Tarihi: 12.06.2021 Makalenin Kabul Tarihi: 05.12.2021

\title{
Suriye’deki Rus Vatandaşı Yabancı Terörist Savaşçıların Rusya'nın İç Güvenliğine Etkileri
}

\author{
Güngör Şahin*, Adnan Aydın**
}

\begin{abstract}
Öz: 11 Eylül saldırıları dünyanın teröre bakışını ve yaklaşımını kökten değiştirmiştir. Ortadoğu'da yaşanan Arap Baharı ve sonrasındaki süreç ise terörizm kavramının insan hayatından hiçbir zaman çıkmayacağını göstermiştir. Günümüzde devletler sadece rakip devletlere karşı değil terör örgütlerine karşı da mücadele etmek zorunda kalmaktadır. Özellikle Suriye’deki terör örgütlerinin ortaya çıkardığı yabancı terörist savaşçı sorunu son yıllarda dünya siyasetinde ve güvenlik politikalarında etkili olan Rusya'nın karşısına birtakım problemler çıkarmaktadır. Bunların en önemlisi ülkeye geri dönen Rus vatandaşı yabancı terörist savaşçıların Rusya’nın iç güvenliğine olan etkisidir. Bu konuda daha derin analiz yapabilmek için çalışmanın konusu "Suriye'deki Rus Vatandaşı Yabancı Terörist Savaşçıların Rusya'nın İç Güvenliğine Etkileri” olarak belirlenmiştir. Makalenin kaleme alınma amacı Rusya’yı güvenlik anlamında etkileyebilecek yabancı terörist savaşçıların Rusya’nın iç güvenliğine olan muhtemel etkilerini bilimsel bir anlayışla incelemektir. Makalenin Rusya’ya dönecek yabancı terörist savaşçlların etkisini özel olarak incelemesi, konuya kavramsal ve kuramsal perspektiften bakması önemini göstermektedir. Makalede araştırma yöntemi olarak nitel araştırma metodolojisi benimsenmiştir. Çalışmanın sonunda ülkesine geri dönen yabancı terörist savaşçıların Rusya’nın iç güvenliğine olumsuz anlamda mutlaka bir etkisinin olacağı bulgusuna ulaşılmıştır.
\end{abstract}

Anahtar Sözcükler: Rusya, Suriye, Yabancı Terörist Savaşçı, Güvenlik, Terörizm.

\footnotetext{
${ }^{*}$ Doç. Dr., Milli Savunma Üniversitesi, Atatürk Stratejik Araştırmalar Enstitüsü (ATASAREN), Strateji ve Güvenlik Araştırmaları Anabilim Dalı Öğretim Üyesi, gsahin@msu.edu.tr, https:// orcid.org/0000-0001-6296-8568.

${ }^{* *}$ Yüksek Lisans Öğrencisi, Milli Savunma Üniversitesi, Atatürk Stratejik Araştırmalar Enstitüsü (ATASAREN), Güvenlik Araştırmaları Yüksek Lisans Programı, utgmadnan@yahoo.com, ORCID: 0000-0001-8010-5360.
} 
ISSN: 2148-6166

Year: 23 Volume: 23 Issue: 2 December 2021 p.158-177 Article Type: Research Received Date: 12.06.2021 Accepted Date: 05.12.2021

\title{
The Impact of Russian Citizen Foreign Terrorist Fighters in Syria on Russia's Internal Security
}

\author{
Güngör Şahin, Adnan Aydın
}

\begin{abstract}
The September 11 attacks have radically changed the world's perspective and approach to terrorism. The Arab Spring and its aftermath in the Middle East showed that the concept of terrorism will never come out of human life. Nowadays, states have to fight not only against rival states but also against terrorist organizations. Especially the problem of foreign terrorist fighter caused by terrorist organizations in Syria creates a number of problems for Russia, which has been effective in world politics and security policies in recent years. The most important of these problems is the effect of Russian citizen foreign terrorist fighters returning to the country on Russia's internal security. In order to make a deeper analysis on this subject, the subject of this article has been determined as "The Effects of Russian Citizen Foreign Terrorist Fighters in Syria on Russia's Internal Security". The purpose of writing the article is to examine the possible effects of foreign terrorist fighters, which may affect Russia in terms of security, on Russia's internal security with a scientific understanding. The article's special analysis of the impact of foreign terrorist fighters who will return to Russia shows the importance of looking at the issue from a conceptual and theoretical perspective. Qualitative research methodology has been adopted as a research method in the article. At the end of the study, it has been found that foreign terrorist fighters returning to their country will have a negative effect on Russia's internal security.
\end{abstract}

Key Words: Russia, Syria, Foreign Terrorist Fighter, Security, Terrorism. 


\section{Giriş}

İnsanoğlu tarımın keşfi sonrasında avclık ve toplayıcılığı terk edip yerleşik hayata geçmiştir. Yeni hayata geçişle birlikte bir arada yaşamanın etkileşimlerini deneyimleyen insanlar, sorunlar ve anlaşmazlıklar yaşamaya başlamış ve nihayet bu sorunlarını çözmek için silahı icat etmiştir. Kökleri tarihin derinliklerinde gizli olan terörizmin baş aktörü insanoğlunun şiddete dayalı davranışları milattan önce başlamış ve günümüze kadar etkisini artırarak sürdürmüştür. Artık çağımızda insanların var oldukları sürece terörün de var olacağı ve onunla birlikte yaşamayı öğrenmeleri gerektiği anlaşılmıştır. İnsanlar istediklerini almak için her dönem teröre başvurmuş özellikle son yıllarda Ortadoğu'da terör, bir yaşam biçimi haline gelmiştir.

Arap Baharı ile birlikte Ortadoğu'da sağlam, demokratik ve sürdürülebilir bir yapısı olmayan ülkelerin yönetimleri sırayla değişmiştir. Ancak Suriye, özellikle Rusya'nın desteği ile bu tehlikeyi atlatmış gözükmesiyle farklı bir model özelliği göstermektedir. Suriye ve Irak’ta etkili olan ve yönetime başkaldıran örgütlerin içinde bu ülkelerin vatandaşı olmayan, dışarıdan gelen teröristlerin taşımış olduğu özellikler çok farklıdır. The Soufan Group Strateji Araştırma Merkezi tarafından 2014 ve 2015 yıllarında yayınlanan Suriye ve Irak’taki Yabancı Savaşçılar Raporları, bu örgütlerin içinde sayı ve etki olarak en önemli olanların Rusya ve Kuzey Kafkasya ülkelerinin vatandaşları olduğunu işaret etmektedir (Gülşen, 2019, s. 17). Bahsi geçen kişilerin örgüte katılma süreçleri, örgüt içindeki faaliyetleri ve kendi ülkesini döndükten sonra yarattığı etkiler, akademik olarak incelenmesi ve zamanında çözülmesi gereken problem sahaları olarak beklemektedir.

Rusya ve Suriye ilişkilerinin II. Dünya Savaşından beri artarak devam etmesi, Suriye'deki örgütlerin içinde Rusya’yı güvenlik anlamında etkileyebilecek yabancı terörist savaş̧̧ı sayısının çokluğu ve Rusya'nın uluslararası ortamda artan etkisi doğal olarak Rusya'yı hedef haline getirmektedir. Bu konuyu detaylı incelemek için bu makalenin konusu “Suriye'deki Rus Vatandaşı Yabancı Terörist Savaşçlların Rusya'nın İç Güvenliğine Etkileri” olarak belirlenmiştir. Makalede ana amaç, Rusya'yı güvenlik anlamında etkileyebilecek yabancı terörist savaşçların Rusya'nın iç güvenliğine olan muhtemel etkilerini kuramsal ve kavramsal çerçeveden bakarak araştırmak, incelemek, değerlendirmek, yapılması ve yapılmaması gerekenleri ortaya koymaktır. Makale esas olarak, özellikle Arap Baharından sonra meydana gelen 10 yıllık süreyi, yabancı terörist savaş̧̧ların Rusya'nın iç güvenliğine etkilerini ve Kuzey Kafkasya bölgesindeki güvenlik konularını kapsamaktadır. Bu kapsam içinde makalenin araştırma soruları, "Yabancı terörist savaşçıların özellikleri nelerdir?", "Yabancı terörist savaşçılardan başka ne gibi tehditler bulunmaktadır?" ve "Yabancı terörist savaşçların etkilerine karşı ne gibi tedbirler alınmalıdır?” olarak belirlenmiştir. Bu sorularla yabancı terörist savaş̧̧ıların özelliklerinin neler olduğuna, Rusya'ya yabancı terörist savaşçılardan başka bir tehdit kaynağı olup olmadığına ve alınması gereken tedbirlere cevap aranacaktır. Makalenin hipotezi, ülkesine geri dönen yabancı terörist savaşçıla- 
rın Rusya'nın iç güvenliğine olumsuz anlamda mutlaka bir etkisinin olacağıdır. Bu konuda yapılan literatür taramasında konu ile ilgili bilimsel araştırmalarda daha çok örgütlere katılan teröristlerin hedef ülkeye etkileri incelenmiş, yabancı terörist savaş̧̧ıların geri dönmeleri durumunda neler yaşanacağını, özellikle de güvenlik anlamında Rusya'da neler olabileceği konularının geri planda kaldığı tespit edilmiştir. Bu anlamda makalenin Rusya’yı özel olarak incelemesi, konuya kavramsal ve kuramsal perspektiften bakmasıyla kendine özgü bir özellik taşıyacak olması önemini göstermektedir.

Makalede araştırma yöntemi olarak nitel araştırma metodolojisi benimsenmiştir. Konuyla ilgili çalışmalar yapılırken literatür analizi tekniği kullanılmıştır.

Salih Zeki Haklı'nın editörlüğünü yaptı̆̆ Radikalleşme Şiddet ve Terörizm adlı kitabın Yusuf Furkan Şen’in kaleme aldığı “Yabancı Terörist Savaşçılar” bölümünde, yabancı savaş̧̧lara ilk örnek olarak 1820 yılında Osmanlı Devleti’nden ayrılmak isteyen Yunanlıların yanında yer alan Britanyalı Savaşçlar verilmektedir. Eserde ayrıca takip eden dönemlerde Amerika'da, İspanya'da ve Arap İsrail Savaşlarında yabancı savaş̧̧ların gittikçe artan sayılarla çatışmaların içinde yer aldığı da belirtilmektedir. Dolayısıyla bu olgunun aslında uzun süredir insan hayatında olduğu bilinmektedir. Bununla birlikte Fatma Taşdemir'in Suriye Çatışma ve Uluslararası Hukuk kitabında Sovyetler Birliği ile Afganistan arasında 1979-1989 yıllarında ve Rusya ile Çeçenistan arasında 1994-2009 yılları arasında gerçekleşen çatışmalarda yer alan yabancı savaşçıların, bu kavramın daha belirgin şekilde öne çıkmasını sağladığı belirtilmiştir. Olgunun yabancı savaşçı teriminden yabancı terörist savaşçı kavramına evirilmesi çalışma içinde detaylı olarak anlatılacaktır.

Bu makalede Suriye'deki Rus vatandaşı yabancı teröristlerin Rusya'ya geri döneceği varsayılmıştır. Çalışmada mekân açısından Suriye, Rusya ve Kuzey Kafkasya ülkeleri; zaman açısından ise 2011-2021 yılları arası gelişen olaylar incelenmiştir. Çalışmanın mantıklı ve makul bir sıra takip edebilmesi için, ilk bölüm olan "Kuramsal ve Kavramsal Çerçeve" başlığında önce Neorealizm yaklaşımı tarihsel gelişim süreciyle ifade edilmiş, Rusya’nın teori çerçevesindeki yaklaşımları ortaya konulmuş, müteakiben kavramsal çerçeve incelenmiştir. Daha sonra “Rusya’nın Suriye Politikası” incelenmiş, ardından “Suriye'deki Rus Vatandaşı Yabancı Terörist Savaşçıların Durumu” ve "Suriye’deki Rus Vatandaşı Yabancı Terörist Savaş̧̧ıların Rusya’nın İç Güvenliğine Etkileri” irdelenmiştir. Konuyla ilgili bulguların yer aldığı "Sonuç" kısmıyla çalışma tamamlanmıştır.

\section{Kuramsal ve Kavramsal Çerçeve}

II. Dünya Savaşı'nın bitmesiyle birlikte güvenliğe duyulan ihtiyaç artmış, bu sebeple uluslararası ilişkiler teorilerinden Realizm diğer teorilere göre ön plana çımıştır. Realizmde insan, doğası gereği bencil kabul edilmekte, daha güçlü olma hırsıyla hareket eden insanın her zaman kendi çıkarını gözettiği düşünülmektedir. Aynı insan gibi devlet de kendi çıkarını gözettiğinden, Realist düşünürler ulusal 
çıarın gözetilmesine çok önem vermiştir. Realist düşüncede esas aktör olarak her zaman ulus devlet önemli görülmüştür. Neorealist düşüncede ise insanın doğası ve devletin kendisi değil uluslararası ortamın güç dengesi önemli kabul edilmiştir. Bu teoride devletin her durumda hayata kalmayı amaçladığı düşünülmektedir (Tezcanlar ve Kılıç, 2020, s. 74-75).

Neorealizm'de devlet adamları kararlarını uluslararası sistemin yönlendirdiği biçimde alırlar. Tek bir hükmedici gücün olmadığı uluslararası sistem, anarşik yapısından dolayı ülkeleri sürekli tehdit ederek kendini korumaya zorlar. Bu düşüncede olan devlet adamları ülkelerinin güvenliğini sağlamak için askeri güç kapasitesini artırarak kendi güvenliklerine daha fazla önem verirler (Altınörs, 2019, s. 11). Arap Baharı ile birlikte Rusya'nın Suriye'nin yanında yer almasının sebebi, oluşabilecek kaos ortamına karşı kendi askeri güvenliğini güneyindeki en uzak noktadan itibaren sağlamak istemesidir. Ayrıca Neorealist yaklaşımda, devlet kendi güvenliğine bir tehdit oluşursa, yaşamını sürdürmek için savunmacı yahut saldırgan olmak üzere iki farklı realist düşünceden birini uygulamak mecburiyetinde kalmaktadır. Savunmacı Realizmde devlet gücünü çoğaltmak yerine elinde bulunan gücü rakip ülke güçleriyle orantılı bir şekilde tutmaya devam eder. Gücünü daha fazla artırarak onlara bir üstünlük sağlamak veya tehdit oluşturmak için çalışmaz. Doğal olarak kimse kimseye bir üstünlük sağlamadığı zaman da herkes kendini güvende hisseder. Kendisine bir tehdit olduğunda ise devlet harekete geçer ve kendini korur. Ancak Rusya bölgede bu seçeneği kullanmamış, Saldırgan Realizm prensibiyle hareket etmiştir.

Saldırgan Realizm yaklaşımı, uluslararası sistemin anarşik yapısından dolayı devletin gücünü artırmasını gerektirir. Çok güçlü devlet hiçbir zaman ondan daha güçsüz devletlerin hedefi olmaz. Bu mantığa göre devlet ne kadar güçlüyse o kadar uzun süre hayatta kalır anlamı çıkmaktadır. Rusya da askeri kapasitesini devamlı surette artırarak bölgede güçlenmeye devam etmesi ile dikkat çekmektedir. Gerçekte Rusya’ya yönelik tehditlerin konvansiyonel olmaktan ziyade iç güvenlik ve yakın coğrafyasındaki radikal hareketler olduğu değerlendirilmektedir (Yılmaz, 2017, s. 806). Ancak yine de Saldırgan Realist bir aktör olarak davranan Rusya hem askeri gücünü artırmakta hem de Suriye'yi destekleyerek aslında kendi ulusal çıkarlarını korumaktadır. Dolayısıyla Rusya, Suriye’nin bütünlüğünü desteklemek için gerekli unsurları ile birlikte bölgede yer almaktadır. Bölgede bulunan terör örgütleri de kendilerine katabildikleri insanları savaşçı haline getirerek kendi emellerini ve ideolojisini uygulamak suretiyle her türlü şiddet eyleminde kullanmaktadır. Dolayısıyla bölgede bazı ülkelerle birlikte Rusya ve terör örgütleri farklı amaçlarla aynı kaotik ortamda yer almaktadır.

Yabancı savaşçı kavramı kuramsal ve tarihsel açıdan incelendiğinde Haçlı Seferlerine kadar geriye gidebilecek bir geçmişe sahip olduğu görülmektedir. Ancak o dönemde henüz Westphalia Barış Anlaşması imzalanmamış ve ulus devlet yapısı oluşmamıştı. Bu nedenle devletlerin egemenliği ve eşitliği, diğer devletin iç işlerine karışmama prensibi sağlam zemine oturmadığından kimin yerli kimin 
yabancı olduğuna karar vermek ve kavramın anlaşılması zor olmaktaydı. Dolayısıyla bu kavram ile ilgili pratik açıdan uygun olan ilk örnek olarak 1820 yılında Osmanlı Devleti'nden ayrılmak isteyen Yunanlıların yanında yer alan Britanyalı Savaşçlar verilebilir. Takip eden dönemlerde Amerika'da, İspanya'da ve Arap-İsrail Savaşlarında yabancı savaş̧̧ılar gittikçe artan sayılarla çatışmaların içinde yer almıştır (Şen, 2018, s. 189). Ancak Sovyetler Birliği ile Afganistan arasında 19791989 yıllarında ve Rusya ile Çeçenistan arasında 1994 ve 1999 yılında başlayan Çeçen Savaşlarında yer alan Arap savaş̧̧ılar (Kartal, 2019, s. 19), bu kavramın daha belirgin şekilde öne çıkmasını sağlamıştır (Taşdemir, 2016, s. 213-246). Yabancı savaşçı kavramı İngilizce kaynakların tamamında "foreign fighter" olarak geçmesine rağmen az sayıda kaynakta "homegrown” terimine de rastlanmaktadır (Demir, 2015, s. 3). "Homegrown” kelimesi sözlük anlamı olarak yerel veya ev yapımı gibi anlamlara gelir. Ama kavram olarak, yetişmesini müteakip savaşmak veya başka türlü terörist faaliyetlerde bulunmak amacıyla başka topraklara giden genelde Batı kökenli vatandaş anlamında kullanılmıştır. Kavram kendi içinde söz konusu ülkeye yabancı olma, gönüllü olma ve bir ideolojiye sahip olunması durumunu barındırmakta (Çona, 2021, s. 280), kişinin yaptı̆̆ faaliyet şiddet içermekteyse terör olgusu da oluşmaktadır.

Yabancı savaşçı kavramı, DAEŞ'in Irak ve Suriye'deki konusu suç unsuru olan eylemleri sonucu sorgulanmaya başlamış, 2014 yılında Birleşmiş Milletler Güvenlik Konseyi (BMGK) tarafından 2178 sayılı kararla net olarak tanımlanmış ve gayrimeşru ilan edilmiştir (Kartal, 2019, s. 19). Konseyde alınan kararla üçüncü bir ülkeden planlama sürecine katılmak, hazırlık yapmak, çatışmak, eğitim yapmak veya savaşmak gayesiyle gelerek terör örgütlerine katılan herkesin yabancı terörist savaşçı kapsamına girmesi kabul edilmiştir (United Nations Security Council Resolution 2178, 2014). Yabancı terörist savaşçı kavramı Türkçe literatürde "YTS", İngilizce literatürde "FTF" (Foreign Terrorist Fighters) olarak kısaltılmış ve bazı yerlerde bu şekilde kullanılmıştır. Burada yabancı savaşçı ile yabancı terörist savaşçı tanımlarındaki farkın terör boyutundan kaynaklandığı gözden kaçırmamak gerekir. Dolayısıyla terör kavramının anlamını bulabilmesi için yabancı terörist savaşçı kavramı bu makalede kısaltılmadan kullanılmış ve böylece anlam bütünlüğünün ve düşünce derinliğinin sağlandığı değerlendirilmiştir.

Birleşmiş Milletlerin (BM) özgürlük savaşçısı kavramı ile terörist tanımı arasındaki ayrım belirsizken yabancı savaşçı ile yabancı terörist savaşçı tanımı arasındaki farkı çok nettir. BM bu konuda terörist faaliyetler içinde olan örgütlere katılmanın yabancı terörist savaşçı sayılmak için yeterli olduğu kararını vermiştir (Terör Çalıştayı Raporu, 2016, s. 11). Bu kararda; ait olduğu devlet dışında başka bir devlete terör eylemi düzenlemek, planlama veya hazırlık yapmak, bunu yapanlara katılmak amacıyla giden kişiler ya da silahlı çatışma konusu dâhil terörizm konusunda eğitim gören veya eğitim veren kişiler yabancı terörist savaşçı olarak kabul edilmiştir (United Nations Security Council Counter-Terrorism Committee, 2018, s. 4). Böylece yabancı savaşçı kavramı teorik olarak hukuki zeminde doğru 
yer bulması için yabancı terörist savaşçı olarak değerlendirilmeye başlanmış, BM üyesi devletlerin bunlarla ilgili hukuki yaptırımlar uygulaması ve üye devletlerin bu kişilerin hareketliliğine engel olması istenmiştir.

Terör ve terörizm kavramının halen tüm dünya tarafından kabul edilmiş bir ortak tanımı olmaması ona karşı kolektif ve daha etkili tedbirler alınmasını engellemektedir. Benzer şekilde yabancı terörist savaşçı olgusuna da her ne kadar BM hukuki tedbir alınmasını istemiş olsa bile tüm devletler tarafından aynı tedbirler alınmamaktadır. Zira bazı ülkeler, kendi orduları ile Silahlı Çatışma Hukuku kurallarına göre savaşmak yerine hedef ülkedeki amaçlarına bu savaşçıları kullanarak ulaştıkları için çatışma bölgesine giden kişilere sadece görünüşte tedbir almaktadır.

Teorik olarak yabancı terörist savaşçı kavramının oluşabilmesi için, kişinin çatışmanın meydana geldiği topraklara ait olmama, bir örgüte ait olma, istekli olma ve belli bir amaca sahip olma gibi unsurları asgari olarak taşıması gerekmektedir. Terörizmin de siyasi bir amaçla, örgütlü ve sürekli bir biçimde terör yöntemlerinin kullanılmasını benimseyen bir strateji şeklinde açıklandığı düşünüldüğünde, tüm terör örgütlerinin veya güvenlik şirketlerinin kullandığı bu kişilerin her bir devlet tarafından yabancı terörist savaşçı olarak değerlendirilmesi elzemdir. Bu değerlendirme sonrası terörist olarak nitelendirilen kişilere hukuki yaptırımlar uygulanması da önem arz etmektedir.

Konuya uluslararası ilişkiler alanında kuramsal bir bakış açısı getirmek için yapılmış bazı tanımlamalar da ayrıca dikkat çekicidir. İlk olarak David Malet’in tanımında başka bir ülkedeki iç çatışmaya katılanların o ülkenin vatandaşı olmaması yabancı savaşçı şeklinde tanımlanması için yeterli görülmüştür. Malet bu tanımın içine teröristlerin yanı sıra paralı askerleri de ilave etmiş ve konuya farklı bir bakış açısı getirmiştir (Yalçınkaya, 2017, s. 26). Başka bir tanım Ian Byran'dan gelmiş, başka ülkelerden gelen ve ulus aşırı bir amaç veya grup için savaşanlar bu kavramın içine sokulmuştur (Yalçınkaya, 2017, s. 26). Mendelsohn ise yabancı savaş̧̧ıya terörist sıfatını eklememiş, ancak tanım yaparken yabancı savaşçıların yer aldıkları savaşta, taraf ülkenin vatandaşı olmamasının şart olduğunu belirterek kavram içinde yer alan yabancı terimine vurgu yapmıştır (Gülşen, 2019, s. 7). Hegghammer ise değişik bir tanımlama yapmıştır. Buna göre yabancı savaşçı tanımı ile bir çatışma veya kalkışmaya taraf olan, karşı ülke ile de bir milliyet bağı olmayan, yasal ve düzenli bir askeri yapıya ait olmayan ve bu faaliyetleri karşılığında herhangi bir ödeme almayan kişiyi kastetmiştir. Hegghammer DAEŞ'in ortaya çıkması ile tanıma ekleme yaparak düşman bir unsura karşı terörizmle ilgili tüm faaliyetler dahil askeri bir harekata katılmak amacıyla herhangi bir Batı ülkesini terk eden veya bu terk etme kararını alan kişi olacak şekle getirmiştir (Gülşen, 2019, s. 7).

Sonuç olarak bu tanımlama çabaları, kavramın merkezindeki kişilerin özellikleri, statüleri ve nereden geldikleri kadar amaçlarının da önemli olduğunu ön plana çıkarmaktadır. Kişilerin bir kısmı intikam alma ve hırs gibi sebeplerle ör- 
güte katılırken başka bir kısmı cihatçı düşünce ile katılmıştır (Gülşen, 2019, s. 11). Ancak genelde baskı görmüş, şiddete maruz kalmış ve ayrımcılık yaşamış kişilerin fazla sayıda olduğu tespit edilmiştir. Bu bağlamda ilave olarak önemli bir problem sahası, mutabık olunan genel bir yabancı terörist savaş̧̧ı profilinin ortaya çıkarılmamasıdır. Ayrıca bu kişileri örgüte kazandıranların aradığı özellikler neredeyse aynıdır. Genelde genç, iyi eğitim alamamış (Kartal, 2019, s. 19) veya eğitim seviyesi düşük, gelir seviyesi düşük, zor şartlarda yaşayan, toplum içinde kendini gösteremediğini düşünen, arkadaşlarından etkilenen, çaresizlik hissi ve zor durumdaki aynı dine mensup insanlara yardım etme düşüncesi içinde olan, sosyal ağlar ve medyadan etkilenen (Keser ve Ulusoy, 2020, s. 238), kendisine haksızlık yapıldığı zanneden, Maslow'un ihtiyaçlar hiyerarşisinde kendisine üst sıralarda yer arayan, hatta sırf heyecan yaşamak isteyen ve dini kulaktan dolma bilgilerle öğrenen kişiler bu örgütlere eleman arayanların hedefi olmaktadır.

\section{Rusya'nın Suriye Politikası}

II. Dünya Savaşı’nın bitmesi ile birlikte Sovyetler Birliği Ortadoğu’ya ilgi göstermeye ve kendisine yakın gördüğü ve ilişki kurmanın yarar sağlayacağını değerlendirdiği ülkelerle diplomatik seviyede ilişkiler kurmaya başlamıştır. Zira Ortadoğu'da İngiltere ve Fransa'nın otoritesini giderek kaybettiğini görmüş ve oluşan boşluğu doldurmak ve bu ülkeleri kendi tarafına çekebilmek için kendisine rakip gördüğü Amerika Birleşik Devletleri’ni (ABD) de hesaba katarak bir takım ikili ilişkiler kurmaya başlamıştır. Bu anlamda Suriye ile Sovyetler Birliği arasında 1946 yılında, eğitim sisteminin kurulması, güçlü bir Suriye Ordusu kurulması için askeri eğitim ve personel desteği ile Suriye topraklarında bulunan yabancı ülke askerlerinin çekilmesi konularında gizli bir anlaşma imzalanmıştır. Bu anlaşma Suriye'ye uluslararası ortamda diplomatik ve siyasi destek sağlamak için Sovyet yardımını da öngörmekteydi (Karabulut, 2007, s. 69). Suriye de Sovyetler Birliği'nin dış politikasına benzer şekilde, 1950 yılından itibaren batı karşıtı politika uygulamaya başlamış, İngiltere ve Türkiye'nin içinde olduğu Bağdat Paktı'na katılmamış, hatta Fransa ile ekonomik ilişkilerini neredeyse bitirmiştir. İzlenen bu siyaset her iki tarafı daha da yakınlaştırmış ve daha fazla alanda ilişkilerini geliştiren Sovyetler Birliği ve Suriye bu kez de 1955 yılında detaylı bir ticari anlaşma imzalamışlardır (Çomak, Sancaktar ve Yıldırım, 2016, s. 360-362).

Suriye'ye Rusya tarafından mali ve ekonomik yardım yapılmasına, kültürel iş birliğine, silah ve askeri malzeme gönderilmesine ABD tepki göstermiş ve iki ülkenin iş birliğine cevap olarak 1957'de uygulamaya koyduğu Eisenhower Doktrini ile cevap vermiştir (Çomak vd., 2016, s. 360-362). Suriye'nin 3 yıllık Mısır'la birleşme macerası Rusya ile ilişkilerine kısa bir süreliğine ara verdiyse de 1960’lı yıllardan itibaren yakın iş birliği tekrar devam etmiştir. 1970'li yıllarda ABD ile Mısır'ın yakınlaşması nedeniyle Rusya ve Suriye ilişkileri de doğal bir refleks 
olarak daha da artmış, karşılıklı ziyaretler, askeri ve ekonomik anlaşmaların sayısı ve kapsamı genişletilmiştir.

Rus Lider Gorbaçov ile birlikte zayıflamaya başlayan ilişkiler Sovyetler Birliği’nin dağılması ile bir süreliğine belirsizliğe sürüklenmiştir. Zira Rusya bu dönemde dağılmanın etkisi ile kendi ekonomik savaşını vermeye, Çeçen meselesi ile uğraşmaya ve bölgesindeki istikrarsızlıkla mücadele etmeye çalışmışır. Rusya Federasyonu Suriye ile ikili ilişkilerde ilk yıllarda gerekli ivmeyi yakalayamamış, 1994 yılında askeri bir anlaşma ile eski silahlarını Suriye'ye satarak ilişkilerin devamını sağlamıştır. 2000’li yıllarla beraber iç sorunlarını halleden Rusya, artan enerji geliri ile Ortadoğu'ya, özellikle de Suriye özelinde bölgeye kuvvetli bir dönüş yapmış ve bölgede kısa sürede Avrupa ve ABD'nin dikkatini çekecek şekilde ağırlığını hissettirmiştir.

Suriye, Çeçen ve Gürcü sorununda her anlamda Rusya’yı desteklemiştir. Örneğin Birinci ve İkinci Çeçen Savaşlarında Rusya'nın yanında yer alan Suriye, Çeçen savaş̧̧ları terörist olarak suçlamıştır (Kreutz, 2010, s. 12). Rusya 2008'de Gürcistan'a müdahale ettiğinde ona destek veren nadir devletlerden birisi yine Suriye olmuştur (Çalışkan, 2016, s. 5). Hatta Suriye, zaman zaman Rus yanlısı Çeçen ve Gürcü liderleri ülkesinde en üst düzeyde ağırlayarak Rusya’yı etkilemeye çalışmıştır. Takip eden dönemde Rus petrol şirketleri Suriye’de faaliyetlerini artırmış, Rusya hidroelektrik santraller ve gaz işletme tesisleri kurmaya başlamış, Suriye'nin eskiden kalan borçlarının önemli bir kısmını silmiş ve Tartus Deniz Üssü’nü modernize etmiştir. 2011 yılında Arap Baharı yaşanırken Esad rejimi Moskova'nın desteğini hep arkasında hissetmiştir. İç savaşta on binlerce sivilin öldürülmesi ve insan hakları ihlalleri sebebiyle Suriye, uluslararası toplumu ikiye bölmüştür. Bir tarafta ABD, Avrupa Birliği, Türkiye, Katar ve Suudi Arabistan Şam yönetimine muhalif olan unsurları desteklerken; diğer tarafta Rusya, Çin ve İran rejimin yanında yer almıştır. Yine aynı dönemlerde Rusya, Birleşmiş Milletler Güvenlik Konseyi’nde Suriye’nin insan hakları ihlalleri yapması sebebiyle çeşitli yaptırımlar uygulanmasını veto ederek Şam yönetimine desteğe devam etmiştir (Taşdemir, 2016, s. 117-126). Ayrıca Suriye'nin Şam yakınındaki Guta'da muhaliflere karşı sarin gazı kullanması sonucu ortaya çıan gerginlikte Rusya ABD'yi ikna etmiş ve Suriye yönetiminin kimyasal silahlarını barış̧̧l yolla imha etmesini sağlamıştır.

Bu dönemde Rusya, mevcut rejimle ilişkileri son derece iyi olduğu için ve mevcut yönetimin yerine gelme ihtimali olan radikal dini grupların kendi ülkesindeki 30 milyon Müslüman vatandaşı ile çevre ülkelerdeki Müslümanları etkilemesi ihtimalinden dolayı Suriye rejiminin yanında yer almıştır. İlerleyen dönemde Rusya'nın haklı olduğu Irak ve Suriye'deki DAEŞ içinde tespit edilen 3000'e yakın Rus (Antunez, 2016, s. 4), 500 civarı Çeçen ve 1000 civarı Dağıstanlı yabancı terörist savaşçı vasıtasıyla ispatlanmıştır (Soufan Group, 2015, s. 12).

Rusya, Suriye'deki iç savaşın bitmesi için uluslararası ortamda çok çaba sarf etmiş, çeşitli ateşkes anlaşmaları yapmış ve kalııı barış için de uğraşmıştır. Ayrıca 
iç savaş devam ederken bile Suriye rejimine ciddi manada kredi desteği sağlamış, gıda, giyecek, ilaç gibi insani yardımlarda bulunmuş, çeşitli askeri donanım satışı ve teknik desteği sağlamıştır. Güç gösterisi yapmak ve destek olmak amacıyla Rus uçak gemisi Amiral Kuznetsov Suriye’nin Tartus Deniz Üssü’ne gelerek Şam yönetimine destek olmuş, İdlib ve Hama'da hava taarruzlarıyla rejim güçlerinin önünü açmıştır. Bunlarla birlikte ateşkesin sağlanması için gösterdiği çabaların yanında ateşkesi kontrol ederek kalııı barış sağlamaya çalışmıştır.

Özet olarak Rusya'nın, Soğuk Savaş’ın başından beri izlediği politikalarla Suriye'nin yanında yer aldığı, ülke bütünlüğünün sağlanmasına yönelik uluslararası ortam dâhil tüm platformlarda askeri, ekonomik ve insani olarak yardım ettiği görülmüştür. Buradaki esas gaye Neorealist yaklaşımla Suriye’yi destekleyerek, terör örgütlerine karşı başarı sağlamasına yardım etmektir. Böylece radikal dinci örgütler güç kaybedecek, örgütlerin içindeki yabancı terörist savaşçların Rusya için bir tehdit olmasının daha başlangıçta önüne geçilecektir. Sonuç itibariyle bu sağlam temelli ikili ilişkiler zaman zaman kesintiye uğrasa dahi Rus yönetimi Şam yönetimini yalnız bırakmamış, kendi çıkarını sağlayacak şekilde desteklemiştir.

\section{Suriye'deki Rus Vatandaşı Yabancı Terörist Savaşçıların Durumu}

Ortadoğu'da yerleşik düzene başkaldırma amacıyla başlayan Arap Baharı ile birlikte Irak ve Suriye'de yaşanan iç savaşlarda yabancı terörist savaşçı kavramı dünya gündemindeki yerini tekrar almıştır. Aslında insanlık tarihi boyunca yaşanan iç savaşlarda daha önce de yabancı savaşçılar görülmüştür. Ancak Irak ve Suriye'de farklı etnik köken ve dini kimlik taşıyan, farklı amaçlar ve hedefler için bu iki ülkeye gelen savaşçılar 2011-2015 yılları arasında neredeyse 25.000 kişiyi geçmiştir. Bunlardan o dönem içinde sadece Suriye’de yaklaşık 1700 civarı Rus vatandaşı, yabancı terörist savaşçı olarak bulunmaktaydı (Taşdemir, 2016, s. 209-213). Irak ve Suriye birlikte hesaplandığında 2015 yılında toplam 3417 Rus vatandaşı savaşçı olarak bölgede yer almaktaydı (Keser ve Ulusoy, 2020, s. 208).

Rus vatandaşlarının yanı sıra Kafkasya'nın kuzey ülkelerinden Suriye’ye yabancı terörist savaşçı olarak gelen kişiler de Rusya açısından, en az Rus vatandaşları kadar önemli sayılmaktaydı. Zira eski Sovyet ülkelerinden 8700 civarı kişinin (Keser ve Ulusoy, 2020, s. 209) Suriye ve Irak’ta DAEŞ'e katılmış olması Rusya açısından önemli bir problem sahası olmuştur. Bahse konu bu kişilerin savaş ortamı bittiğinde Rusya'ya ve civarına dönerek terörizme konu olacak faaliyetler içinde bulunma ihtimali yüzünden 2016 yllında Rusya, Suriye topraklarında askeri müdahaleye karar vermiştir (Gülşen, 2017, 15 04). Ancak başlangiçta ne Rus vatandaşı teröristlerin ne de Kuzey Kafkasya'dan gelen teröristlerin sayısını bilmek doğal olarak imkânsızdı. Dahası bunların hangi örgütlerin içinde yer aldığı ne uğruna savaştığı ve amacının ne olduğu da belirgin değildi. Bahsi geçen örgütlerden biri olan DAEŞ, Batılı ülkelerde yaşayan insanların daha faz- 
la ilgisini çekmesi ve daha fazla kişinin katılması bakımından diğerlerine göre farklılık arz etmektedir. İngiltere'de bu konularda incelemeler yapan Uluslararası Radikalleşme Çalışmaları Merkezi'nin 2018 yılında yaptığı bir araştırmada toplamda 40.000'den fazla kişinin DAEŞ saflarına yabancı terörist savaşçı olarak katıldığı ortaya çımıştır (Cook ve Vale, 2018). Bunlar, çoğunluğu Afrika olmak üzere Rusya, Kuzey Kafkasya, Orta Asya ve Batı Avrupa ülkeleri dahil 80 ayrı ülkeden gelerek örgüte katılmıştır (Jenkins, 2019). Örgüte katılanlardan başka, henüz kendi ülkesinden çıkamadan veya hedef ülkeye varamadan yakalananlar bu sayılara dahil değildir. Yine bu kişilere örgüte katılma safhasına gelse bile çeşitli şekillerde vazgeçen veya fikrini değiştirenler de dahil edilmemiştir. Katılan kişi sayısının ne kadar çok olduğunu istihbarat örgütleri sayesinde öğrenen Rusya bu konuyu analiz ederken, Rus vatandaşları ile Kuzey Kafkasya ülkeleri vatandaşları arasında bir ayrım yapmamayı tercih etmiş̧ir. Zira sonuçta bu savaşçıların, dönüşte Rusya’ya veya Kuzey Kafkasya’ya geri dönmesi, güvenlik zafiyeti anlamında Rusya ve onun eski istihbaratçı lideri Putin için fark etmeyecekti. Putin'e göre Kafkasya'daki dini ve etnik temelli akımlar Rusya'yı mutlaka etkileyecektir (Kartal, 2020, s. 341). Bu kapsamda 2015 yılında Rusya tarafından istihbarat birimlerine dayanarak yapılan değerlendirmede, çok sayıda Rus ve Kuzey Kafkasya kökenli yabancı terörist savaşçının, Irak ve Suriye'de DAEŞ'e katıldığı istihbaratı edinilmiş ve kamuoyuna açıklanmıştır (Gülşen, 2017, 15 04). Tam da bu noktada farklı ihtimaller ortaya çımmaktadır. Birincisi bu kadar çok hem de benzer yaş, kişilik ve fiziki özelliklerde Rus ve Kuzey Kafkasya ülkeleri vatandaşının farklı gerekçeler göstererek kısa bir sürede ülkelerini terk edip Irak ve Suriye’de DAEŞ’e katılmak amacıyla gelmesi nasıl olmuştur da Rus İstihbaratının dikkatinden kaçmıştır? Başka bir ihtimal olarak söz konusu kişilerin, Rusya'dan ayrılmasına göz yumarak iç güvenliğe olabilecek tehditlere karşı ülkeyi daha güvenli hale getirme politikasından bahsedilebilir (Keser ve Ulusoy, 2020, s. 219). Durum böyle de değilse diğer bir ihtimal Suriye'deki iç savaşa müdahale konusunda Rusya'nın politikasının ipuçlarını verebilecektir. Zira Ruslar tüm dünyanın gözünün önünde cereyan eden iç savaşa dışarıdan bir aktör olarak meşru müdahalenin formülünü bulmuştur. DAEŞ saflarına katılan o kadar çok Rus vatandaşı ve Kuzey Kafkasya ülke vatandaşı vardır ki iç savaş bitiminde veya bitmeden herhangi bir zamanda bu terörist savaş̧̧lar geriye döndüğünde kendi güvenliği için çok riskli olacaktır. Bir taktik olarak bu bilginin kirli bilgi olma potansiyelini de hesaba katmak gerekir. Zira herkes tarafından sonradan öğrenilen gerçek şudur ki Suriye'de devam eden iç savaşta özellikle görsel/yazılı medya ve daha çok sosyal medya kullanılarak tüm aktörler yanlış bilgilendirmeye sık sık başvurmuştur. Rusya’nın da böyle bir yöntem kullanma ihtimali mevcuttur.

Gerçekte her durumda Rusya, Suriye’ye gelerek DAEŞ saflarında çatışmaya katılan, iç savaş, çatışma ortamı ve çeşitli tekniklerle asker veya masum insanlara saldırma konusunda tecrübe kazanan bu yabancı terörist savaş̧̧ıların er ya da geç bölgeye geri döneceğini biliyordu. Bu anlamda en büyük tehditlerden biri olarak, 
Suriye içinde kendi başına El-Muhacirin ve Şişani (Çeçen) adlı cihatçı örgütleri kurabilecek kadar radikal olan Çeçen kökenli savaşçılar örnek olarak gösterilebilir (Dursunoğlu ve Eren, 2014, 977). Çeçenler içinde istismar edilebilecek kişiler için bir örnek olay olarak, Rusya’nın İkinci Çeçen Savaşında aşırı güç kullanması ve bu hassasiyet yüzünden radikal kişilerin hedefi haline gelmesi verilebilir. Bu şekilde istismar edilerek kandırılan ve Rusya'ya karşı yapılacak eylemlerde kullanılmak ve yetiştirilmek üzere DAEŞ’e katılmış Çeçen kökenli yabancı terörist savaşçıların, istenildiği yer ve zamanda terörist bir eylemle Rusya'ya karşı, ABD’ye yapılan 11 Eylül saldırılarının benzeri eylemlerde kullanılabilmesi olasılığının yüksek olduğu değerlendirilmektedir.

Suriye'deki Rus vatandaşı yabancı terörist savaşçların yanında sayısı onlar kadar olmasa da bölgeye gönderilmiş özel güvenlik şirketleri çalışanlarının da ayrı bir risk konusu olarak Rusya'nın karşısına çıkması muhtemeldir. Rusya bu konu ile ilgili 2008 ve 2012 yılları arasında çeşitli yasal düzenlemeler yapmış ve stratejik öneme haiz Rus şirketlerinin yurtdışındaki tesislerinde güvenliğin sağlanması maksadıyla özel güvenlik görevlilerine hukuki olarak izin vermiştir. Hatta bu şirketlere silah kullanma yetkisi ve güvenlik eğitimine ilave olarak profesyonel askeri eğitim verilmesi için yasal altyapı dahi oluşturulmuştur. Yine bu şirketlerin askeri teçhizata sahip olmasına hükümetin kontrolü altında olmak kaydıyla izin verilmiştir.

Rus lider Putin'in özel güvenlik şirketlerine çok önem verdiği o dönem basına yaptığı açıklamalarla dünya kamuoyu tarafından öğrenilmiştir. Bu konuda halen Libya'da aktif olarak faaliyet gösteren Wagner'in yanında RSB, Redut, Anti-Terör Güvenlik Şirketi ve Moran Güvenlik Şirketi gibi kurumların sadece Suriye'de değil Ukrayna'da da kullanıldığı ve bu gibi şirketlerin sayılarının artarak çeşitli meşru ve gayri meşru işlerde kullanıldığı bilinmektedir. Ancak bu konuda, mevcut şirket elemanlarının askeri hiyerarşik yapıda olmamaları, iç işleyiş kurallarının tam oturmaması, disiplinin tesis edilmesindeki zorluklar ve Suriye gibi asimetrik tehditlerin ve hibrit savaşların yaşandığı bir bölgede kontrol ve denetim zorluğundan dolayı birtakım sıkıntıların yaşanması doğal kabul edilmektedir (Gülşen, 2017, 22 02).

Ayrıca bu şirketlerden en ünlüsü olan Wagner'in sahibinin Putin tarafından özel olarak ödüllendirilmiş olması hükümet denetim görevlilerinin bu şirket elemanlarını kontrol etmesini zorlaştırmaktadır. Bu risklerin yanında özel güvenlik şirketlerinin Suriye'de çok kayıp verdiği, hayatını kaybedenlerin ailelerinin evlatlarını aradığı, ancak bir haber alamadığı, hatta cesetlerin gemilerle Rusya'ya gizlice getirildiği gibi iddialar, bu kişilerin görev bitişi geri dönüşlerinde hassas yapılarından dolayı istismar edilerek Rusya'ya karşı terör unsuru olarak kullanılabileceğini göstermektedir. Dolayısıyla Rusya tarafından Suriye'deki hibrit savaş ortamında özel güvenlik şirketleri kullanılması ve burada kullanılan kişilerin geri dönmesi ile oluşacak tehdit, yabancı terörist savaşç̧ ile aynı riski taşımaktadır.

Söz konusu risklerin yanında Rusya'nın bölgede özel güvenlik şirketlerini kullanmasının birtakım getirileri de olmaktadır. Illk olarak bu şirket elemanlarının 
faaliyetleri sayesinde Rusya, ülke olarak istediklerini elde etmekte ancak uluslararası hukukta özne olmamaktadır. İşlenen suçlarda muhatap özel şirketler olmaktadır. Bu durumdan Rusya, BM üyesi bir devlet olarak Silahlı Çatışma Hukukuna uygun olmayan taktiklerle hedeflerini elde etmek isterse özel güvenlik şirketlerini kullanabilir sonucu çıkmaktadır. Sorumluluk BM üyesi olarak imzaladığı Viyana Antlaşmalar Hukuku Sözleşmesi'nin 26'ncı maddesine göre Rusya'ya değil herhangi bir anlaşma imzalamamış olan özel güvenlik şirketine aittir (Vienna Convention, 1969). Diğer taraftan söz konusu şirket elemanları hayatını kaybettiğinde bunun basına yansıması ve etkisi bir Rus ordu mensubu kadar olmayacaktır. Aynı zamanda bu şirketlerin başarısız operasyonlarının sonucu ve sorumluluğu Rus ordusuna değil şirkete ait olacaktır.

Yine de ülke içindeki Rus vatandaşlarının da bu durumları bilmesi yüzünden etik olarak Rusya bu yükü taşımak zorundadır. Ayrıca ifade edilen onca avantajlı hususa rağmen, Suriye'de birçok hukuk dışı eylem yapmak zorunda bırakılan bu görevlilerin yurda geri döndüğünde yabancı terörist savaşçılar kadar riskli grup içinde olacak olması kaçınılmazdır.

\section{Suriye'deki Rus Vatandaşı Yabancı Terörist Savaşçıların Rusya'nın İç Güvenliğine Etkileri}

Yabancı terörist savaşçıların Suriye ve Irak'ta DAEŞ’e katılıp daha sonra kendi ülkelerine döndükleri zaman meydana getirecekleri riskler sadece Rusya’yı değil tüm Batı ülkelerini ve genel olarak tüm dünya ülkelerini ilgilendirmektedir. Ancak konunun Rusya için önemli ve öncelikli olma sebebi kendi ülkesinin yanında Kuzey Kafkasya dahil tüm eski Sovyet ülkelerinin riskini de taşımasından kaynaklanmaktadır (Şen, 2018, s. 193-195). Batılı bir ülkeye kıyasla, nispeten daha büyük ve karışık bir coğrafyada, sayı ve etki olarak çok daha fazla geri dönen yabancı terörist savaşçı ile mücadele edileceği düşünüldüğünde durumun Rusya için ne kadar zor olduğu anlaşılmaktadır.

Konuya bir örnek olarak başta Belçika ve Fransa olmak üzere 2014-2016 yılları arasında Avrupa'da eski DAEŞ mensubu ve ülkesine geri dönmüş yabancı terörist savaşçların toplam 38 eylemi sonucu onlarca kişinin yaşamını kaybetmesi verilebilir (RAN Centre of Excellence, 2017, s. 15). Bu örnekte görüldüğü üzere, kendi ülkesinden kimlerin DAEŞ’e katıldığını, kimlerin yabancı terörist savaş̧̧ı olarak terörist eylemlerde bulunduğunu, kimlerin geri döneceğini bilemeyen ülke olası riskleri de doğal olarak hesaplayamamaktadır. Bu riskler yabancı terörist savaşçı sorununu Rusya açısından daha da içinden çıkılmaz hale getirmektedir. Zira Suriye'de bulunan Rus vatandaşı yabancı terörist savaş̧̧ı sayısı diğer ülkelerle kıyaslandığında çok daha fazladır. Bu riskin yanında Kuzey Kafkasya ülkeleri vatandaşlarından da bu şekilde geri dönme durumu olan çok daha fazla yabancı terörist savaşçı bulunduğu değerlendirilmektedir. Zaten iki yıkıcı savaş geçirmiş 
olan Kuzey Kafkasya bölgesinde bulunan ayrılıkçı ve cihatçı radikaller, normal koşullarda bile Rusya için bir tehdit sayılmaktadır. Hatta bu konuda Rusya Federal Güvenlik Servisi (FSB), Suriye'de bulunan radikal terörist unsurların bir kısmının çatışmaya yatkın Müslüman nüfusa sahip Dağıstan, İnguşetya ve Çeçenistan'a sızma ihtimalinin çok yüksek olduğunu açıklamıştır (Çomak vd., 2016, s. 365-366). Bu kişilerin dini motivasyonla eylem yapması durumunda 30 milyona yakın Müslüman vatandaşı bulunan Rusya'nın bu durumdan aşırı etkilenmesi beklenmektedir. Yine bu kişilerin diğer ülke istihbarat örgütleri tarafından yönlendirilmesi ve istismar edilmesi durumunda daha sansasyonel etki yaratacak eylem yapabilme kapasitesi de ayrıca ortaya çıkabilecektir. Zaten bu kişilerin kaybedecek hiçbir şeyi kalmamıştır. Suriye'ye giderken her şeyi arkalarında bırakarak gitmiş ve kendi sonlarının ne olacağını hesap etmemişlerdir. Dolayısıyla geri dönen kişilerin aile birliği ve eski yaşam düzenleri muhtemelen bozulmuş olacaktır. Bozulmasa dahi detaylı bir çalışmayla bile topluma entegrasyonu çok daha zor olacak ve entegrasyon çalışmasının uzun yıllara yayılması gerekecektir (UNSCC-TC, 2018, s. 4). Zira bu kişiler Suriye'de saldırmayı, terör ve şiddet eylemleri planlamayı ve icra etmeyi öğrenmiş ve uygulama düzeyinde defalarca tekrar etmişlerdir. Hatta muhtemelen uzunca bir süre toplumdan uzak gruplar içinde, sağlıksız ve elverişsiz şartlarda bir hayat yaşamışlardır. Bu kişiler her ne kadar çatışma bölgelerinden uzaklaşmış olsalar da halen oradaki bağlarını ve iletişimini bir şekilde devam ettiriyor olabilirler. Böylece yeni geldikleri yerlerde hem propaganda faaliyetlerinde yer alabilir hem de uyuyan hücre pozisyonuna geçebilirler (Üstün, 2020, s. 1035). Ayrıca çatışma alanından gelmiş bu kişilerin farklı bir yetenek, ilgi alanı, hobi veya mesleki bilgilerinin olması da beklenemez. Adeta hepsi birer ölümcül silah gibidir. Korku kavramını kaybetmiş olduklarından intihar tipi eylemler dahil tüm terör eylemlerini planlama ve icra etme yeterliliğine sahip oldukları göz önünde bulundurulmalıdır. Bu kişilerin mensup olduğu örgütleri terk etme sürecinden itibaren izlenmeleri ve topluma dahil edilmeden önce ihtiyaçlarının neler olacağı baştan sona analiz edilmelidir. Hukuki olarak bu kişilerin yargılanması ve hapis cezası almaları kaçınılmazdır. Ancak bu konuda bu tür bir yaklaşımın tek başına sorunu tamamen çözmesi beklenemez. Ceza yargılaması yapılması yanında önleme ve rehabilitasyon çalışmalarıyla ceza politikalarının birbiriyle pekiştirilmeleri gerekmektedir (Reed ve Pohl, 2017). Yeniden entegrasyon ya da yeniden katılma adı verilen bu süreçte paket program hazırlanarak sosyal, psikolojik, maddi, sağlık ve meslek edindirme gibi hayatı kolaylaştırıcı faaliyetlere başvurulmalıdır (Demir ve Pala, 2020, s. 23). Bu faaliyetler yapılırken de bütüncül anlayışta bir yasal mevzuata, ceza ve adalet sistemi dahil kurumlar arasında ve toplumla iş birliği ve koordinasyona ihtiyaç duyulmaktadır (Avcl, 2019, s. 451).

Bu konuyla ilgili 2017 yılında yapılan bir araştırma sonucunun bulguları dikkate değerdir. ABD merkezli The Soufan Center araştırma şirketinin raporunda DAEŞ saflarında Irak ve Suriye'de savaşan ve 2017 itibariyle geriye dönen yabanCı terörist savaşçılardan en fazla sayısı olanların eski Sovyet ülkelerinin vatandaş- 
ları olduğu belirtilmiştir (Keser ve Ulusoy, 2020, s. 209). Bunların çoğunluğunu Rus vatandaşları oluştururken Kuzey Kafkasya ülkelerinin vatandaşlarının sayısının da azımsanmayacak kadar çok olduğu belirtilmiştir. Bu durumun ciddiyetinin farkında olan Putin, Suriye’deki Rusya veya Kuzey Kafkasya ülkeleri vatandaşı yabancı terörist savaşçıların bölgeye geri dönmemesinin kendi güvenlikleri için çok önemli olduğuna defalarca dikkat çekmiştir. Zira bu kişilerin bölgeye geri dönmesi Rus iç güvenliği bakımından diğer Batılı ülkelere kıyasla daha fazla bir tehdit oluşturacaktır (Gülşen, 2017, 15 04). Bu konuda 2017 yılında Çeçenistan'daki bir Rus askeri tesisine düzenlenen terörist eylemde 7 askerin hayatını kaybetmesi örnek olarak verilebilir. Yine aynı yıl Petersburg şehrinde bir intihar saldırısı yapılmış ve 14 sivil Rus vatandaşı hayatını kaybetmiştir. Başka bir bölgede yapılan eylemde 2 Rus Polis öldürülmüştür. Tüm bunlar Rusya'da geri dönen yabancı terörist savaşçıların Suriye'deki çatışmalarda elde ettikleri tecrübelerini kullanarak ses getiren eylemler yapma kapasitesini göstermektedir. Eylem yapma kapasitesinin gittikçe artacağı değerlendirildiğinde Rusya'nın daha fazla etki gösterecek yeni terörist eylemlerle karşı karşıya kalacağı değerlendirilmektedir. Diğer taraftan Suriye'de rejime karşı kalkışan terör örgütlerinin içinde yer alan yabancı terörist savaşçılar, burada başarılı olmaları durumunda özellikle Kuzey Kafkasya'da dini motifli radikallere esin kaynağı olacaklardır (Çomak vd., 2016, s. 369). Hatta bu olası başarı zincirleme reaksiyonla Güney Kafkasya ve Orta Asya ülkelerine de sirayet etme ihtimalini beraberinde getirmektedir.

$\mathrm{Bu}$ alanda yaşanacak zorluklardan birisi de yabancı terörist savaşçılardan yaşı küçük olanların sayı olarak fazla olması ve suça sürüklenen bu çocukların çatışma alanında büyümeleri, karakterlerinin savaş ortamında şekillenmesinden sonra ülkeye geri dönmesidir. Bu çocukların topluma uyum sağlama sürecinin daha sancılı ve belirsiz olması beklenmektedir (Gülşen, 2019 Nisan, s. 19).

Rusya ve Kuzey Kafkasya ülkelerinden Suriye'ye giden yabancı terörist savaşçıların Rusya'yı terk etmiş olmaları sonucunda Rusya içinde ve bölgede güvenlik anlamında rahatlama olmuş ve bu kişilerin DAEŞ'e katılması, dolaylı olarak Rusya iç güvenliğine olumlu yönde katkıda bulunmuştur (Gülşen, 2017). Konu sadece bu kadarla kalmamış, Suriye topraklarında DAEŞ adına savaşan özellikle Rus vatandaşı yabancı terörist savaşçıların bizzat Rusya tarafından Suriye topraklarında etkisiz hale getirilmesi durumu, başka bir olgu ortaya çıkarmıştır. Zira Rusya bu hareketiyle, 11 Eylül saldırılarından sonra ABD’nin de yaptığı gibi, kendi iç güvenliğini başka ülke topraklarında sağlamak gibi bir olayın baş aktörü olmuştur. Bu şekilde etkisiz hale getirilen yabancı terörist savaşçı sayısı tam olarak bilinmemektedir. Ancak Rusya'nın iç güvenliği için tehdit olarak kabul edilen ve eylem yapma inisiyatifi gösterebilecek kişilerin, sayıları ne olursa olsun etkisiz hale getirilmesi şüphesiz ki Rusya’ya mutlaka bir avantaj sağlamıştır.

Çağımızda yabancı terörist savaş̧̧ılar ile ilgili değişik risk içeren konulardan birisi de örgütlerin sosyal medya ve diğer iletişim metotlarını kullanarak küresel 
bir ağa sahip olmalarıdır. Terör örgütleri sosyal medya sayesinde kolayca örgütlenebilmekte, organize olup silahlı ya da silahsız eylemlere eleman sağlayabilmekte ve hatta yapacakları eylemler için bile bu mecrayı kullanabilmektedir (Sönmez, 2017, s. 68). Özellikle DAEŞ, sosyal medyaya hâkim bir örgüt olup bu sayede çok sayıda yabancı teröristi bünyesine katmıştır (Kartal, 2018, s. 67). Birçok farklı ülke kaynağından yabancı terörist savaş̧̧ıları kendi saflarına çekme konusunda çok etkili olan örgüt, özellikle kendini boşlukta hisseden, henüz kişilik olarak olgunlaşmamış ve sanal ortamda arayışta olan gençlere sosyal medya sayesinde kolayca ulaşabilmektedir. Örgüt herkesin izleyebileceği bir anlatım dili ve kurgu geliştirerek bilgisayar oyunları oynayan, Hollywood tarzı film izleyen, sosyal medya vasıtalarını sıklıkla kullanan ve popüler kültür simgelerine aşina olan gençlere yönelik bir strateji izlemiş, böylece küresel çapta sosyal medyada geniş kitlelere mesajlarını iletmiştir (Göksun ve Salihi, 2018, s. 11). Örgüt sosyal medyayı kullanırken kontrolsüz davranmamış aksine "Medya Divanı" adlı alt unsuru ile propaganda ve eleman temini faaliyetlerini koordineli bir şekilde yürütmüştür. Propaganda ve eleman temini için kullandığı en önemli dergiler Al Manba, Dabiq, Dar Al Islam, Konstantiniyye ve Rumiyah olup özellikle İngilizce, Fransızca, Almanca, Rusça, Türkçe ve Kürtçe dillerinde yayın yaparak çok geniş kitlelere hitap etmeyi hedeflemiştir (Göksun ve Salihi, 2018, s. 19-20).

DAEŞ'in özellikle Kuzey Kafkasya'da sosyal medya ağları üzerinden eleman temini ve para toplama gibi faaliyetlerde bulunurken Facebook, VKontakte ve Odnoklassniki gibi sosyal medya sitelerini kullandığı, ayrıca ShamToday gibi medya gruplarıyla birlikte Rusça internet siteleri açtığı tespit edilmiştir (Yılmaz, 2020, s. 76). Ayrıca Kuzey Kafkasya, Irak ve Suriye'de bulunan ve Rusça bilen elemanları arasında irtibat sağlamak ve tebliğ yapmak amacıyla Fırat Medya adındaki internet televizyonu platformunu devreye sokmuştur (Yllmaz, 2015, s. 673). Bunlardan başka video paylaşma imkânı sunan YouTube platformunu yeni eleman toplamak, iletişim sağlamak ve propaganda yapmak için etkili şekilde kullanmıştır (Taşdemir, 2017, s. 741).

Rusya DAEŞ'e katılımın önlenmesi için Kafkasya'daki cumhuriyetlerle iş birliği yapmış, din adamları, emniyet teşkilatı ve sivil toplum kuruluşları ile birlikte başta sosyal medya olmak üzere tüm alanlarda fiili olarak tedbir almanın yanında hukuki yaptırımları da etkili olarak kullanmıştır. Bu önlemleri alırken örgüte katılan Rus vatandaşlarının ailelerini de unutmamış onlara yardımcı olmak için çağrı merkezi bile kurmuştur. Rusya, Müftüler Birliği aracılığıyla DAEŞ karşıtı sosyal bir doktrin hazırlatmış, ülke gençliğinin bilinçlenmesi amacıyla eğitim müfredatına DAEŞ tehlikesine dikkat çekmek için ders ilave etmiştir. Tüm bunların yanında FSB tarafından Kuzey Kafkasya'da DAEŞ'e yönelik nokta operasyonları yapılarak örgütün etkinliği azaltılmaya çalışılmıştır (Yılmaz, 2020, s. 75-82).

Rusya, eski Sovyetler Birliği ülkelerinden Kolektif Güvenlik Antlaşması Örgütüne (KGAÖ) üye ülkelerle terörizmle mücadele konusunda ikili ilişkiler 
kurmaktadır. KGAÖ tarafından terör örgütlerine yönelik istihbarat paylaşımı ve operasyon yapmak amacıyla kurulan ve terörizme karşı ortak mücadele ettikleri iş birliği platformu olan "Ortak Acil Müdahale Gücü” sayesinde 2012 yılından itibaren Orta Asya’da, Tacikistan ve Afganistan sınırlarında terör örgütlerine yönelik operasyonlar yapılmıştır (Gafarlı, 2016).

\section{Sonuç}

Sonuç olarak Suriye'ye yabancı terörist savaşçı olarak gidenlerin hayatta kalanları zayıf da olsa aile bağlarını devam ettirmek, kendini göstermek ve başka gerekçelerle mutlaka ülkesine geri dönüş yapmak isteyecektir. Bununla ilgili sorumluluğu ve alınması gereken güvenlik önlemlerini tüm ülkeler sağlamak durumundadır. Ancak Suriye'de bulunan Rus vatandaşı yabancı terörist savaşçı sayısının fazla olması ve bunun yanında Kuzey Kafkasya ülkeleri vatandaşlarından da bu şekilde çok kişi bulunması sebebiyle Rusya daha hassas durumdadır. Dönen vatandaşların aile birliği muhtemelen bozulmuş olacaktır. Bozulmasa bile entegrasyonu çok daha zor olacak ve uzun yıllara yayılması gerekecektir. Bu kişilerin uzun zamandır terörizmden başka bir faaliyette bulunmamaları sebebiyle ister yasal yollarla geri dönsün isterse yasa dışı yollarla geri dönsün, Rusya'da yasadışı faaliyetlerde özellikle terör faaliyetlerinin içinde bulunma ihtimali çok yüksektir. Bu da Rusya'nın iç güvenliğine olumsuz etki yapacaktır.

Öncelikle geri dönen bu kişiler yargı sürecinden geçirilmeli, iç ve uluslararası hukuk kurallarına göre yargılanmalıdır. Müteakiben Rusya tarafından ayrı bir birim kurularak dışarıda ve hapishanede olanlar için farklı algoritmalar kullanılarak entegrasyon planları yapılması gereklidir. Zira Avrupa ülkeleri dahil tüm gelişmiş ülkeler aynı soruyu kendilerine sormaktadır: Yabancı terörist savaşçılar ülkeye geri döndüğünde ne yapılacaktır? Bu sorunun cevabı net olarak verilip detaylı planlama ile topluma entegrasyonu sağlanmazsa ilk boşluk bulduklarında veya problem yaşadıklarında şiddet veya saldırı seçeneklerinden birini, diğer bir ifade ile terörü hayata geçireceklerdir. Bu kişilerin yasal yollarla veya yasadışı yollarla ülkeye geri dönmesine göre tedbir alınması da başka bir problem sahasıdır.

Yabancı terörist savaşçı temin etmek amacıyla son yıllarda özellikle sosyal medya ve benzer yöntemleri kullanan örgütlere karşı Rusya tarafından kamuoyunu bilgilendirecek şekilde tedbir alınması ve halkın bilinçlendirilmesi önem arz etmektedir.

Ülkesine geri dönen yabancı terörist savaşçlardan az sayılabilecek oranda kişinin döndükten sonra kendi ülkelerinde şiddet ve terör içeren faaliyetlerde bulunması ihtimaline rağmen bir olay bile zamana ve şartlara bağlı olarak çok önemli olabilmektedir. Zaten şiddet ve terör eylemlerine az sayıda kişi karışmasına rağmen, bu kişilerin çoğunluğunun ağırlıklı olarak aşırı radikal grupların güç kazanması için diğer destek faaliyetlerinde bulunması dikkat çekmektedir. Bu riskli 
duruma karşı tedbir alan Avrupa Konseyi aldığı kararla ülkelerine geri dönen yabancı terörist savaşçıların mutlak surette yargılanmalarını kendi birlik ülkelerine şart koşmuştur. Yargılanma sonunda hüküm giyenlerin hapishanede dahi radikal grupların ağına düşebileceklerine dikkat çekilmiştir. Benzer durum Rusya için de geçerlidir. Dünyanın hangi ülkesinde olursa olsun, hapishanelerde yeterli tedbir alınmaz ve gerekli izolasyon sağlanmazsa buralar birer eğitim kampına dönüşmektedir. Özellikle radikal dini motivasyonlu örgütler bu fırsatları değerlendirme konusunda uzmanlaşmıştır. Gelişen teknolojisi sayesinde Rusya’nın bu kişileri her yerde takip etme imkânı bulunduğu değerlendirilmektedir. Rusya'nın, ülkesine geri dönen yabancı terörist savaşçıları, yalnız polisiye tedbirlerle ve klasik istihbarat örgütlerinin kullandığı yöntemlerle topluma entegre etmesi beklenemez. Soruna ideolojik ve kültürel olarak mücadele edebilecek enstrümanlarla müdahale edilirse sonuç alınabileceği değerlendirilmektedir. Bu yöntemin de yabancı terörist savaşçıların örgüte katılma noktasına kadar geri gidecek uzun soluklu bir müdahale sürecini kapsaması gerekecektir.

\section{Kaynakça}

Altınörs, M. N. (2019). Soğuk Savaş Döneminde İran ve Türkiye’nin Dış Politikasındaki İttifak Tercihleri: Benzerlikler ve Farklılıklar. (Yüksek Lisans Tezi). Başkent Üniversitesi Avrupa Birliği ve Uluslararası İliş̧kiler Enstitüsü, Ankara.

Antunez, J. C. (2016). Islam in Russia: Challenge or Opportunity? https://global-strategy. org/islam-russia-challenge-opportunity/ adresinden erişildi.

Avcı, E. (2019). Ceza Adalet Sistemi Çerçevesinde Şiddet İçeren Radikalleşmeyle Mücadele: Terörist Rehabilitasyonu ve Yeniden Topluma Kazandırma. Uluslararası Güvenlik Kongresi. 19-20 Eylül 2019, Ankara: Jandarma ve Sahil Güvenlik Akademisi Yayınlanı, ss. 439-453.

Cook, J. ve Vale, G. (2018). From DAESH to Diaspora: Tracing the Women and Minors of Islamic State. ICSR Report. https:/icsr.info/wp-content/uploads/2018/07/ICSR-ReportFrom-Daesh-to-\%E2\%80\%98Diaspora\%E2\%80\%99-Tracing-the-Women-and-Minorsof-Islamic-State.pdf adresinden erişildi.

Çalışkan, B. (2016). Rusya-Suriye İlişkileri ve Ortadoğu Krizlerine Etkisi. https:// www.insamer.com/tr/rusya-suriye-iliskileri-ve-ortadogu-krizlerine-etkisi_273.html adresinden erişildi.

Çomak H., Sancaktar, C. ve Yıldııı, Z. (2016). Uluslararası Politikada Suriye Krizi, İstanbul: Beta Yayınları.

Çona, Ö. (2021). Yeni Savaş Ortamında Eski Bir Aktör: Yabancı Terörist Savaş̧̧ılar ve Yeni Çatı̧smalardaki Rolleri. Savunma Bilimleri Dergisi. 39, s.75-303.

Demir, C. K. ve Pala. M. E. (2020). İstikrar ve Yeniden Yapılandırma Faaliyetlerinde Türkiye Örneği: Fırat Kalkanı ve Zeytin Dalı Harekât Bölgeler. Ankara: Jandarma ve Sahil Güvenlik Akademisi Yayınları.

Demir, H. (2015). Yabancı Savaşçlar ve Homegrown Teröristler. Türkiye Ekonomi Politikaları Araş̧ırma Vakfı Değerlendirme Notu. Mart 2015.

Dursunoğlu, A. ve Eren, İ. (2014). Suriye’de Vekalet Savaşı. İstanbul: Önsöz Yayıncılık. 
Gafarlı, O. (2016). Eski Sovyet coğrafyasında DAEŞ varlığı. http://www.aljazeera.com.tr/ gorus/eski-sovyet-cografyasinda-daes-varligi adresinden erişildi.

Göksun Y. ve Salihi E. (2018). DEAŞ’ın Medya Stratejisi. https://setav.org/assets/ uploads/2018/01/98.-DAES\%CC\%A7-tam-rapor.pdf adresinden erişildi.

Gülşen, H. (2017, 22 02). Suriye’deki Rus Özel Güvenlik Şirketleri. Aljazeera Turk. http:// www.aljazeera.com.tr/gorus/suriyedeki-rus-ozel-guvenlik-sirketleri adresinden erişildi.

Gülşen, H. (2017, 15 04). Rus Pasaportlu Yabancı Savaşçllar. Aljazeera Turk. http://www. aljazeera.com.tr/gorus/rus-pasaportlu-yabanci-savascilar? adresinden erişildi.

Gülşen, H. (2017, Temmuz). Rusya’nın Suriye Müdahalesinde Özel Askeri Şirketlerin Rolü. Ortadoğu Araştırmaları Merkezi Bölgesel Gelişmeler Değerlendirmesi No: 64. Ankara.

Gülşen, H. (2019, Nisan). Radikalleşme Bağlamında Yabancı savaşçıların Evrimi. Ortadoğu Araştırmaları Merkezi Rapor No: 4. Ankara.

Jenkins, B. M. (2019). Options for Dealing with Islamic State Foreign Fighters Currently Detained in Syria. CTC Sentinel. https://www.ctc.usma.edu/options-dealing-islamicstate-foreign-fighters-currently-detained-syria/ adresinden erişildi.

Karabulut, B. (2007). Karadeniz’den Ortadoğu’ya Uzanan Bir Dış Politika: Geçmişten Günümüze Suriye-Rusya İlişkileri. Karadeniz Araştırmaları Dergisi. 15, s. 69.

Kartal, A.B. (2018). Uluslararası Terörizmin Değişen Yapısı ve Terör Örgütlerinin Sosyal Medyayı Kullanması: Suriye'de DAEŞ ve YPG Örneği. Güvenlik Stratejileri Dergisi. 27, s. 39-77.

Kartal, A.B. (2019). Yabancı Terörist Savaşçıların Yarattığı Sorunlar ve kaynak Ülkelere Etkileri: Orta Asya. A.B. Kartal ve Ç.Y. Çakan (Ed.), III. Uluslararası Terörizm ve Güvenlik Konferansı Bildiri Kitabı içinde (s. 18-27). İstanbul: Beykent Üniversitesi Yayınları.

Kartal, A.B. (2020). Kafkasya ve Orta Asya Jeopolitiğinin Sorunlar ve Dondurulumuş Çatışmalar Açısından İncelenmesi: Büyük Güçler ve Türkiye. M.C. Oğultürk ve G Şahin (Ed.), Jeopolitik Düşünce içinde (s. 310-350). İstanbul: Yeditepe Yayınevi.

Keser, A. ve Ulusoy, B. (2020). Bırakınız Gitsinler, Bırakınız Savaşsınlar (Laissez Jihad): Kafkasya’dan DAEŞ’e Katılım Nedenleri. Güvenlik Stratejileri Dergisi. 34, s. 203-243.

Kreutz, A. (2010). Syria: Russia's Best Asset in the Middle East, Paris: NIS Center. https:// www. ifri.org/sites/default/files/atoms/files/kreutzengrussiasyrianov2010.pdf adresinden erişildi.

Polis Akademisi. (2016). DAEŞ, Radikalleşme ve Yabancı Terörist Savaşçllar. Terör Çalıştayı Raporu. Ankara: Polis Akademisi Yayınları.

RAN Centre of Excellence. (2017). Responses to Returning Foreign Terrorist Fighters and Their Families. RAN Centre of Excellence. https://ec.europa.eu/home-affairs/sites/ default/files/ran_br_a4_m10_en.pdf adresinden erişildi.

Reed, A. ve Pohl J. (2017, 14 07). Ülkelerine geri dönüş yapan yabancı terör savaşçllarının artan sorunlarıyla başa çlkmak. NATO Review. https://www.nato.- int/docu/ review/ tr/articles/2017/07/14/uelkelerine-geri-doenues-yapan-yabanci-teroer-savascilarininartan-sorunlariyla-basa-cikmak/index.html adresinden erişildi.

Soufan Group. (2015). (Rep.). Foreign Fighters: An Updated Assessment of the Flow of Foreign Fighters into Syria and Iraq. https://www.jstor.org/stable/resrep10784 adresinden erişildi.

Sönmez, G. (2017). Sosyal Medya, Toplumsal Hareketler ve Terörizm. Ortadoğu Analiz. 9 (81), s. 68. 
Şen, Y. F. (2018). Yabancı Terörist Savaşçılar. S. Z. Haklı (Ed.). Radikalleşme Şiddet ve Terörizm içinde (s. 189-211). Ankara: Polis Akademisi Yayınları.

Taşdemir, E. (2017). Sosyal Medyada Terör Propagandası: DEAŞ Örneği. Gümüşhane Üniversitesi İletişim Fakültesi Elektronik Dergisi. 5 (2), s. 741.

Taşdemir, F. (2016). Suriye Çatışma ve Uluslararası Hukuk. Ankara: Nobel Yayıncılık.

Tezcanlar, A. M. ve Kılıç, K. (2020). Güvenlik Çalışmaları. G. Şahin ve M.C. Oğultürk (Ed.), Stratejik Düşünce ve Güvenlik içinde (s. 67-105). İstanbul: Yeditepe Yayınevi.

United Nations Security Council Resolution 2178. (2014). United Nations Security Council Resolution 2178 Adopted by the Security Council at its 7272nd meeting, on 24 September 2014.

United Nations Security Council Counter-Terrorism Committee. (2018). The Challenge of Returning and Relocating Foreign Terrorist Fighters: Research Perspectives.

Üstün, M. T. (2020). Suriye İç Savaşında Yabancı Savaşçılar. Atatürk Üniversitesi İktisadi ve İdari Bilimler Dergisi. 34(3), s. 1021-1043.

Vienna Convention on the law of treaties, Concluded at Vienna No:18232. (1969, 23 05). https://treaties.un.org/doc/publication/unts/volume\%201155/volume-1155-i-18232english.pdf adresinden erişildi.

Yalçınkaya, H. (2017). IŞİD’in Yabancı Savaşçıları ve Yarattığı Tehdit: Türkiye’nin Tecrübesi (2014- 2016). Uluslararası İlişkiler Dergisi. 14 (53), s. 23-43.

Yılmaz, S. (2015). Rusya’nın Suriye Müdahalesinin Gerekçesi: Kuzey Kafkasya’da Irak Şam İslam Devleti (IŞİD-DAEŞ) ve Kafkasya Emirliği Tehdidi. Yeni Türkiye Dergisi. 21 (71), s. 673.

Yılmaz, S. (2017). Uluslararası Güvenlik, Teori Pratik Gelecek. Ankara: Kaynak Yayınları. Yılmaz, S. (2020). Rusya'nın Suriye Politikası. Ankara: İlbilge Yayıncılık Eğitim. 